\title{
The Queerest of the Queer: Sexuality, Politics and Music on the Brisbane Scene
}

\section{Jodie Taylor}

\begin{abstract}
Brisbane's queer scene is relatively obscure, outside of those who actively participate in it, little is known of it and practically nothing is written about it. Broadly speaking, queer culture works in direct contrast to the coherent and commodified culture of the gay mainstream and collectively rejects conventional 'gay music' favouring instead a multiplicity of musical styles and performances. This is particularly evident in the local context where queer clubs and events were born to facilitate the musical desires of those dissatisfied with the music spun weekly at mainstream gay venues.

This paper will demonstrate how the local queer scene's musical eclecticism corresponds with its multifarious performances of queer sexuality, suggesting that queer musical performances and events produce a musico-sexual synergy that accommodates an array of sexual perversities and musical tastes. This paper will look at both the musical performances and related identity performances that occur in Brisbane's queer club scene and queer social events, focusing particularly on the scene's accommodation of 'alternative' musical tastes. Supporting material gathered from interviews with scene participants will provide the basis for a critical examination of Brisbane's queer music scene, and will be placed in the perspective of contemporary discourse on both queer and musical identities.
\end{abstract}

Keywords: queer; gay; music; scenes; gender identity; sexuality; queer theory

\section{Setting the scene}

Queensland and its capital city of Brisbane has a contentious homosexual history. Due to strict legislation against public displays of homosexuality, such activity was confined to certain bars, public toilets and private homes for a large part of the $20^{\text {th }}$ century (see Moore 2001). From 1957 until 1989 Queensland was governed by conservative politics. National party leader, Sir Joh Bjelke-Petersen, held an autocratic rule between 1968 and 1987 that was unsympathetic to the lesbian and gay liberationist efforts petitioning for change elsewhere around the country (particularly in South Australia, Victoria and New South Wales). Queensland was one of the last states to enact homosexual law reform, finally decriminalizing homosexual activity in 1990 and continues to uphold unequal age of consent laws which currently stand at 18 years for anal sex while vaginal and oral sex is permissible at age 16.

During the last 40 years of lesbian and gay political struggle in Australia, contention has arisen amongst conservative and radical factions, that is, those who want to be 'normalized' and those who choose to celebrate their marginality. While essentialist and assimilationist agendas sought to establish the homosexual as a legitimate minority group in order to gain rights and privileges enjoyed by heterosexual citizens, these same agendas simultaneously perpetuated homosexuality and heterosexuality as impermeable categories, positioning them in binary opposition to each other (Corber and Valocchi 2003; Jagose 1996). Furthermore, many queer radicals claim that gay assimilation has resulted in the commodification of sexual identity and the production of a narrow constitution of the gay citizen (Sycamore 2004).

Music provides a concrete example of the commodification and homogenization of the homosexual citizen and gay culture. Recent attempts at targeting the pink dollar ${ }^{i}$ have seen an abundance of so-called 'gay' music compilation discs hit the market over the last 10 years in particular. Series titles such as Gay Dance Music Series (DJ Select), Gay Happenings (Dance Street), Let's Hear it for the Boys (Atlantis Records), Gay Classics (Hot Productions), and Gay Anthems (Almighty Records) are just a handful of examples, all of which feature scantily clad 'buffed' men between the ages of 20 and 35 in highly sexualised poses on their album covers. Moreover, they point to the gross generalization that gay music equates to dance music, thus (according to these examples) the gay citizen is male, physically attractive, aged somewhere between 20 and 35 and a consumer of dance music. This is a stereotype that we see reproduced to some extent within the gay club scene in this local context. These products, which serve as 
just one example $\mathrm{e}^{\mathrm{ii}}$ of commercialized and homogenized sexual identity, are artefacts of the gay mainstream that queer culture is striving to dismantle.

In their notable histories of gay liberation Wotherspoon (1991), Moore (2001) and Reynolds (2002) have pointed out that during the late 1980s and 1990s gay culture in Australia became increasingly bourgeois and assimmilationist. In response to this push towards co-option and assimilation, Moore suggests that the gay mainstream spawned “"deviant” subcultures which have much the same relationship to the mainstream gay culture as the earlier gay and lesbian subculture once had to the mainstream straight culture' (2001, 191). Brisbane's queer scene is an example of such a deviation, in many ways it could be looked upon as the rebellious child of gay assimilation. In a local context, the queer scene has developed around a desire to create a space where queer identified people can come together, listen to and play a variety of musical styles, and perform their queer identity in a multitude of ways that are not socially permissible in either heterosexual or mainstream gay contexts.

Grounded firstly in a thorough understanding of queer and musical identity theories, this paper will look at expressions of gender, sexuality and musicality that occur in Brisbane's mainstream gay venues as well as Brisbane's underground queer venues. Furthermore, it will provide a queer scene ethnography that offers some insight into the disparities between local gay and queer scene culture from a queer perspective. The term 'scene' as opposed to 'subculture' has been employed throughout this discussion because as Peterson and Bennett (2004) note, it is a useful way of articulating how clusters of people distinguish themselves based on a commonality of musical tastes (and in this case, distastes). Moreover, drawing on the work of Gelder and Thornton (1997), Peterson and Bennett argue that the term subculture generally presumes that its participants mark a cohesive deviation from a shared dominant culture and are governed by unified subcultural standards. The term 'scene' does not carry with it such assumptions, and thus it is more fitting for a discussion that focuses on a queer scene since, as Jagose claims, 'queer retains ... a conceptually unique potential as a necessarily unfixed site of engagement and contention' (1996, 129).

Considering the relative obscurity of both scenes outside of those who actively participate in them, the data presented in this analysis has primarily been drawn from my own complete membership ${ }^{\text {iii }}$ within both the gay and queer scene; participant observations that have been made while attending both gay and queer clubs and events in Brisbane over the past four years; interviews conducted with scene participants between February 2005 and November 2007; and online texts sourced from the official websites of the clubs and events in question. Drawing on these resources this paper will highlight the ways in which the queer scene currently sets itself apart from what it characterises as the gay mainstream, focusing specifically on the disparities between musical tastes and sexual conduct. Moreover, it will reveal that queer musical performances and events produce a musico-sexual synergy that accommodates an array of sexual perversities and musical tastes by demonstrating how the queer scene's musical eclecticism corresponds with its multifarious performances of queer gender and sexuality.

\section{Unpacking queer (theory) in a local context}

The positive reappropriation of queer from what was once a pejorative term of reference to lesbian and gay identity began in the mid 1980s and since then has further evolved into a term of resistance positioning itself against the binary organisation of one's gender and sexuality. According to Meyer, “"queer" ... indicates an ontological challenge to dominant labelling philosophies, especially the medicalization of the subject implied by the word "homosexual," as well as a challenge to the discrete gender categories embedded in the divided phrase "gay and lesbian”' (1994, 1-2). Since the advent of queer theory, queer has become much more than an umbrella term for lesbian, gay, bisexual or transsexual identity. It is more than simply another word in the homosexual lexicon—like fag, or dyke-relating to homosexual behaviour. It is a radical form of self-identification that starkly contrasts the terms lesbian and gay. As Sedgwick points out: 
Anyone's use of the word "queer" about themselves means differently from their use of it about someone else ... "gay" and "lesbian” still present themselves (however delusively) as objective, empirical categories governed by empirical rules of evidence. ... "Queer” seems to hinge much more radically and explicitly on a person’s undertaking particular, performative acts of experimental self-perception and filiation. $(1993,9)$

Both Jagose (1996) and Phelan (1997) recognise that queer is particularly concerned with interrogating the notions of fixed, coherent, unified and transparent identity categories. While Butler (1990) reminds us that gender and sexual identities are in no way natural or stable, suggesting instead that gender is constructed by a series of repeated gestures understood as performative. Queer is not lesbian or gay, suggests Butler (2001), but rather it is an argument against lesbian and gay specificity and the idea that being lesbian or gay presupposed that we perform our gender and sexuality in a particular, fixed manner. There is of course contention over the usefulness of these definitions, as some scholars have argued that such ambiguous theoretical suppositions fail to account for lived experience (see Edwards 1998; Plummer 1998). Yet, within a local context, it would appear that the emergence of queer theory has had a strong effect on the way that people self-identify in terms of their gender and sexuality as the majority (but not all) of the interviewees noted that they were aware of queer theory to some extent. The ways in which they had come to know this however, were quite varied: Some suggesting that it was through past involvement in or knowledge of ACT UP ${ }^{\text {iv }}$ and Queerruption ${ }^{\mathrm{v}}$; some had encountered it in tertiary level gender studies; while others had heard of it in general social discussions.

When scene participants were questioned in regard to the way they conceptualized the local Brisbane scene as well as their own queer identities a cohesive relationship emerged between queer theory and actual lived experience. This is exemplified in the follow selection of statements made by queer identified people from the Brisbane scene. SG, a queer musician, event organiser and scene participant, states that:

[The queer scene is] constantly changing and evolving ... and is about generating discussion and discourse around the politics of queer. ... And given that the nature of queer is pretty ephemeral I'd say my queer identity is pretty ephemeral too. Queer is a good opportunity to mix and mash, to take little bits from here and take little bits from there to create your own identity. (pers. comm.)

Many scene participants have, at some point in their lives, been active participants in both the gay and queer scenes and when questioned in regards to their perceived distinctions between the two a similar response was received. As an active member and deejay on both scenes NC remarks that, 'sometimes the gay community has an expectation that everyone should behave a certain way, but that is not a part of being gay and you don't have to do that ... the community itself holds us back with all these labels' (pers. comm.). Scene participant SB responded to the question arguing:

\footnotetext{
The Brisbane queer scene is generally more accepting of difference than the gay scene. While both scenes are not mutually exclusive the queer scene seems less about (but not totally without) hierarchy and judgment. ... A Queer scene for me consists of people and/or spaces where anything goes. Whether it's gender, space, politics, sexuality, dance, attitude or dress, it's a scene where I expect interpretation of self to be freely and comfortably expressed. (pers. comm.)
}

Based on my own observations I give caution to the idea that anything does indeed 'go', a point that SB briefly touched on when he suggested that the queer scene is not totally without hierarchy. As with any scene grouping there are bound to be internal political disagreements. In this scene such disagreement has arisen over the conduct in public sex spaces and BDSM (bondage, discipline, sadism and masochism) performances. Some lesbian identified scene members feel that these spaces and performances discriminate against women, while other women have expressed an opposing view, arguing that they find it to be an accommodating space. The majority of interview participants however, expressed the latter view. The overwhelming response regarding the nature of the Brisbane queer scene was that a queer scene 
provides its participants with an experimental space in which they are able to, or at least expect the freedom to, 'try on' different styles of self-presentation.

Exemplifying the performative and theoretically unfixed quality of queer identity, local queer musician, PJ notes that:

I think a queer scene is what Omo [a queer nightclub] has been where you've got gay male identified, lesbian identified, straight identified, bisexual identified and then you've got interested other parties who just found their way in. People don’t really care ‘cause they're all queer and that's just it. I identify as a gay male in regards to sexuality but I snog [intimately kiss] all my female friends, and we all just play around, 'cause a good snog is a good snog so I never let gender get in the way of that. Omo is an environment where things like that aren't misinterpreted as anything else and that's what I think a queer environment is, one where there's no confusion over labels. (pers. comm.)

The above comment by PJ—referring to a same-sex sexually attracted man who enjoys intimately kissing and 'playing around' with women-reveals that the queer label emerges in opposition to fixed models of identity, refuting definition based upon material sexual practices. It is acts such as these that underscore much of the rhetoric of queer, pointing out as Meyer has that 'queer sexualities are a series of improvised performances', and it is performances such as these that threaten the homo/hetero binary through 'the denial of any social identity derived from participation in those performances' $(1993,3)$.

As the theoretical and ethnographic data shows, Brisbane’s queer scene works in contrast to the culture of the gay mainstream, a culture which many local queers feel has begun to reproduce the gender, sexual (and musical) normativities of straight society. PJ further testifies to this:

\footnotetext{
The gay community is like a condensed version of 'normal' society with so many straight lines running through it. ... That's the problem with the gay inverted commas scene in Brisbane at the moment ... now that they've homogenised and pasteurised themselves for public consumption. (pers. comm.)
}

The gay scene referred to above is geographically located in the inner city Brisbane suburb of Fortitude Valley and can be further isolated to three main nightclubbing venues, these are: The Wickham; the Beat

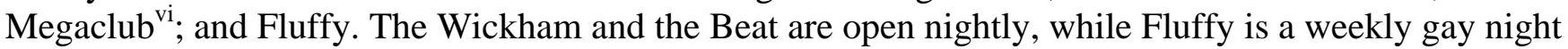
hosted by Brisbane's largest and most famous nightclub, the Family. In contrast, the queer scene-which is partly locatable in Fortitude Valley but extends to other inner city suburbs such as Spring Hill and West End-does not congregate at fixed locations. Instead, queer scene participants congregate at a variety of club events produced by fellow scene members that occur at various 'available-for hire' locations on a semi-regular basis. The queer club events which will be examined here are: Omo (queer and alternative club); Cut and Taste (queer and alternative club); Taboo (queer, alternative and fetish club). Before I begin this examination, it is important to consider the current thinking on music as a resource for the construction and expression of identity and its proposed function within local gay and queer scenes.

\section{Musical identities and musico-sexual synergies}

Over the past 30 years, sociologists and social psychologists have conducted extensive research into music as a marker and constructor of both individual and collective identities. This has lead to the broad acceptance of the idea that music informs personal development and facilitates scene formation. Music is personal because it allows us to manage our feelings, to regulate our moods and negotiate the parameters of aesthetic agency and it is a strategic resource in the production and transmission of self-narrative (DeNora 2002). Music is also social insofar as it is something we do and share with others, either as cocreators, performers or listeners. Music allows us to form social identities because musical tastes and practices facilitate group membership and build social alliances (Hargreaves et al. 2002). Therefore, music is a multi-purpose tool for conducting various identity work.

Frith argues that the 'interplay between personal absorption into music and the sense that it is, ... something public, is what makes music so important in the cultural placing of the individual in the social' 
$(1987,139)$. And as such music potentially provides disenfranchised people (such as queers) with a means of overcoming the public/private dichotomy that has long operated as a means of sexual repression. Music is one way we can facilitate exercises of self-creation upon ourselves while negotiating the self we are creating in relation to normative codes of conduct. This idea is further articulated in the work of Connell and Gibson who suggest 'music can provide opportunities for individuals or groups to assert human agency, to avert cultural homogeneity, to resist symbolically the wider social order and capitalist modes of production, and negotiate hegemonic ideology' (2003, 272). This particular function of music is especially beneficial to queers. It is used extensively in queer work to facilitate the contestation of boundaries allowing queers to individually and collectively negotiate the margins of acceptable behaviour and transgress them. The aesthetic and performative qualities of music coupled with its fluidity, temporality and looseness of meaning make it perfectly suited to expressions of queerness. Moreover, providing a 'safe space' for these expressions because of music's theatrical and fanciful nature (Morris 2006).

Music, like gender and sexuality is performative in that it constitutes a set of acts that are attributed to one's identity. At once music can reinforce a range of appropriate behaviours while also allowing for the exploration, construction and negotiation of alternative social behaviours and ways of 'being' in the world (McClary 1991). As Connell and Gibson suggest, 'music contributes to the gendering and sexualisation of a space through its role in the creation and maintenance of identity' (2003, 210). And while this is true in the case of both gay and queer scenes in Brisbane there are distinguishing factors in the way that music makes its contribution to these scenes. In local gay culture I will demonstrate how it is a singular musical style (that the queer community have dubbed handbag music) which contributes most significantly to the maintenance of gay identity, thus, perpetuating the commodified dominant notion of gay male identity which was outlined previously. In queer spaces however, I will argue that while music similarly contributes to the gender and sexualization of space, here we see how the multiplicities of queer gender and sexual identities in turn contribute to the multiple musical stylings of queer space. Queer musical spaces function in much the same way as theories on queer gender and sexual identity performance. Queer theory accounts for a multiplicity of sexual perversities and in turn the queer scene accommodates a diverse array of musical tastes. It is in the space where these dissonant and resonant sexual and musical performances occur-creating a musio-sexual synergy — that this local queer scene emerges.

\section{Scene sounds and sexual politics}

\section{The local gay scene}

'Gay music' has long been associated with styles of dance music. Gill suggests that 'the dancefloor has always been a holy space ... but it is particularly so among men and women attracted to their own sex' (1995, 134). Dyer has written that 'disco's romanticism provides an embodiment and validation of an aspect of gay culture' $(1995,413)$. Currid argues that house music can be read in part as a 'narrative of 'gay community solidarity' through time and place' $(1995,176)$. While Buckland's (2002) ethnography of the New York gay scene similarly suggests that dance music and dance spaces are vital sites upon which the construction of gay/queer identities and communities happen.

This centrality of dance music to both gay and queer communities is not something I wish to contest. Dance music and dance spaces are something that continue to be of equal importance to both the gay and queer scenes in Brisbane, this is evident in both the interview data and observations presented here. However, what distinguishes these two scenes in this instance is the different styles of dance music and other forms of musical entertainment featured in Brisbane’s gay and queer spaces.

The musical entertainment offered at the Wickham, the Beat and Fluffy is broadly identified as commercial house music. According to the respective websites of each club, the Wickham generally describes the music they play as 'vocal and uplifting house'; the Beat describe their music as commercial, camp classics, pop and vocal house; while the deejay’s weekly updated play-lists on Fluffy’s website 
similarly exhibit a preference for house music. Most deejays that play at these clubs hold long-term residencies, therefore club attendees are generally exposed to the same deejays spinning the same style of music each week with little variation. A typical selection of popular artists that have been recurringly deejayed at these venues would include Kylie Minogue, Madonna, Britney Spears, The Rogue Traders, Ricky Lee, Slinkee Minx ${ }^{\text {vii }}$.

Amongst the queer scene much of the music that is played at such mainstream gay venues is colloquially referred to as 'handbag music'. Music journalists and scene commentators loosely define the term as a form of up-tempo commercial house music, heavily influenced by disco, usually featuring soulful diva-style vocals, long piano breaks which generally has a 'cheesy' happy feel (Fritz 1999; Rietveld 2003). The term, which Fritz (1999) and Thornton (1997) suggest originated in Northern England, is a pejorative reference to groups of women who would congregate on nightclub dance floors, place their handbags on the ground and dance around them. In its original context the term loosely refers to the mainstreaming of rave culture and house music in the early 1990s, suggesting that once this style of music had achieved popularity amongst commercial music fans, the subversiveness and subcultural capital that this music was originally afforded had lost its potency (Thornton 1997). These kind of club goers (those who dance around their handbags) are thought not to take the music or the dance experience seriously, representing a mainstream sensibility, and by extension house music was labelled handbag due to its growing appeal to commercial tastes or to people who are perceived by 'serious' scene participants as lacking individual taste or style.

While this definition of handbag music has clearly arisen far from the locality of Brisbane's gay and queer scenes, it is a term that has been appropriated by members of Brisbane's queer scene and applied to the styles of music (mainly vocal house music) that is typically played in local gay venues. As Thornton (1997) notes in her exploration of subcultural capital and its social logics, the tendency for one scene to distinguish itself in opposition to the mainstream-positioning the mainstream as 'other', homogenous and commodified — can be understood as a tactical discursive strategy in the struggle for power between closely associated scene groupings. Thus, the pejorative use of the term handbag in the local context has a dual effect: At once it marks the queer scene’s resistance of gay mainstream musical tastes while also pointing to the queer scene's discriminating strive for self-worth and/or scene validation through the approbation of minority (and denigration of commercial) style. The close and historic association of gay and queer culture and lifestyle would suggest that the queer scene would be particularly invested in the propagation of such distinctions if they are to create a scene identity that is understood as separate from (what they view as the homogenization of) the gay mainstream.

A distaste for what the queer scene collectively names handbag music is notable in many of the comments made by scene participants and event organisers. According to SG:

\footnotetext{
We've all been in clubs before and said 'god this music is shit' and that will ruin your night, it really will. If it's one handbag song after another then you feel like crap but if it's something you're relating to then that will allow you to amplify the good time that you're having. I think that the music facilitates that and allows it to happen. (pers. comm.)
}

Music that would be classified as handbag by the queer community might, for example, include dance remixes of music by mainstream gay icons such as Kylie Minogue or Madonna. The popularity of these artists amongst both straight and gay communities is reflected in their recurrent polling within music charts, the frequency with which they are heard in clubs such as the Wickham, the Beat and Fluffy, and the alliances these artists have made with gay culture ${ }^{\text {viii }}$. Kylie and Madonna provide simple testimony to the mainstreaming of gay musical sensibilities and reflect the homogenisation of gay cultural identity and mainstream music tastes. As such, Madonna, Kylie and similar diva-vocal house styles of music are strongly rejected by members of the queer scene; this rejection forms a fundamental oppositional act. Queer scene member and musician KD recalls:

In queer clubs the music is more diverse and it just tends to be defined as alternative queer by not being Kylie, Madonna etc. that you usually get at the gay venues. ... When I went to uni in my teens and early 
20s there was still a cliché around that gay clubs had the best music, and I'm sure it wasn't quite true but at least gay clubs had good dance music or at least they weren't playing just top forty pop stuff, and by definition the music they were playing wasn't really charting, well some of it was, the diva type stuff of course. But really since the 90s gay clubs internationally have been playing the worst kind of music in my opinion. (pers. comm.)

Another feature characteristic of gay musical entertainment and performance is low camp drag. The Wickham, the Beat and Fluffy each have their own local celebrity drag queens in residence who, on a weekly basis, perform highly choreographed and flamboyantly stylised lip-synching routines to (and in rare instances actually sing) a variety of handbag pop songs. At the time this research was conducted, all bar one of the resident drag performers at these venues were biological males (the exception being a maleto-female transsexual), who were in all cases backed by 'body-beautiful' and generically stylized dancing chorus boys. The style of drag performed at these venues is particularly low camp as it tends to emphasise the performer's fraudulent femininity through grotesque or absurdly false representations of women. The use of crass humour-particularly humour that is derogatory towards women and female sexualityappears to be generally accepted conduct.

Drag is a significant gay/queer cultural artefact, in many cases it transcends entertainment and offers a valuable critique of gender as performance, potentially subverting dominant gender norms and creating new gender and sexual categories (Butler 1990, 1993; Halberstam 1998). Thus drag performance can be a powerful form of queer political praxis through its potential to critique the connection between body and biology and expose gender as pretence. However, the absence of drag king performers, biological females or masculine identified female performers in mainstream gay venues, is testament to the privileged position of the gay male amongst this scene. This generic style of mainstream gay male drag performances such as those featured at these venues can be read as a fortification of dominant hyper-feminine stereotypes. Some feminist scholars claim that men in drag (drag queens) are making a mockery of womanhood and by only performing dominant stereotypes of privileged white femininity they are simply reifying hegemonic gender norms and power relations (Feigen 2000; hooks 1992; Phelan 1993; Schacht 2002).

Gender identity performances within the mainstream gay scene appear largely prescriptive and a social code of homosexual exclusivity is casually enforced: That is, men that attend these clubs are assumed to sexually desire other men; women are assumed to sexually desire other women. In the majority of cases the biological sex of a person appears to dictate their performance of gender. However, there are limited exceptions to this, as female-identified males and male-identified females were occasionally visible. In my observations of the three aforementioned gay venues a common physical and clothing style was evident among the club's attendees. Both males and females are typically Caucasian, youthful (35 years or under), slender, body-toned and well-groomed with short hair, wearing casual, non-descript clothing. A very small proportion of attendants have large or obese bodies while people wearing alternative or fetish styles of clothing are rare. These observations are further supported by perusing the local lesbian and gay street press: Queensland Pride and Qnews. In each edition of these publications a selection of candid scene pictures taken at the Wickham, the Beat and Fluffy are printed ${ }^{\mathrm{ix}}$.

The sexual identity performances of gay scene participants can be loosely organised into two main binary categories, these being gay male and lesbian female. Based on observations it can be concluded that the gay scene is predominantly populated by gay men who assume the most prominent roles of club organiser, deejay, performer, and punter and subsequently by lesbians who in smaller numbers, assume the roles of deejay and punter. Public sex play is also frowned upon in mainstream gay spaces and if at all present it is generally hidden from view or confined to toilet cubicles. Within this scene public displays of lust or affection are compatible with those one might witness at straight clubs such as sexy dancing, kissing and clothed physical contact. People who have engaged in sexual activity in gay club spaces (including public toilets) have reported being escorted from the nightclub and not allowed back in for the duration of the evening. 


\section{The local queer scene}

In her notable work on queer and transgender subcultures, Halberstam (2005) has shown that locality, musical style and oppositional ideologies — specifically queer's propensity for disidentification —are significant factors in queer scene/subcultural formation. Queer cultures 'oppose not only the hegemony of dominant culture,' argues Halberstam, 'but also the mainstreaming of gay and lesbian culture' (2005, 61). While the locality of Halberstam's work, which is situated in a Euro-American context, is distinct from the Brisbane scene, her ideas illuminate the processes of queer scene formation and reaffirm the significance of style, oppositional politics and scene locality. In regards to the latter, I propose that the locality of the club events in question are also intertwined in the production of local gay and queer scenes. Gay club events occur on a regular basis at fixed locations, while queer events occur on semi-regular basis at random 'available-for-hire' locations. The queer scene is newer, it is community driven and largely selffunded, which would account for its lack of fixed real estate. However, the argument could also be made that the locative fluidity of queer scene events is, in fact, a reflection of the very nature of queer. That is, that the fluidity and indeterminacy professed by queer theories has filtered down and can be identified in the basic structure and organization of the events to be discussed.

Born out of frustration with Brisbane's established gay scene, Omo was one of the first and the longest running queer events in Brisbane. The idea for Omo emerged when two scene members (KD and SG) were returning from a recent trip to Sydney. On the road-trip home KD commented to SG, 'how can we go back to Brisbane and have our entertainment limited to the Beat and the Wickham?' So it was decided at this point that, 'we should just start our own club' (pers. comm.). Built upon a strong do-ityourself ethic Omo operated in Brisbane at semi-regular intervals between 2000-2006. ${ }^{\mathrm{x}}$ Within a few months of Omo's final event in June 2006 two other queer events appeared: Cut and Taste launched its first event in November 2006 and Taboo was launched in December of the same year. It would seem that Omo was the catalyst for queer events to come. The activation of two new queer events so soon after the closure of Omo would suggest that queer scene members did not want to lose touch with the networks they had formed.

Discussions with the founding organizers of Omo stipulated that, 'Omo was about providing a space for people to play in' (pers. comm.). DeChaine argues that 'a playful sensibility can wage a powerful assault on "serious" cultural normativity' $(1997,9)$. This idea of play as an oppositional tactic is central to queer cultural practice and underpins both the sexual and musical characteristics of the local queer scene. The eclectic deejay sets, the live musical performances and the sexual performativity of all queer events to be discussed here encapsulates this sensibility of play. Thus, I propose the musical play, that is the variety of genres and performance styles accommodated by the queer scene, is a simulacrum of the gender and sexual play embodied by queer scene participants. Such gender and sexual play might, for example, include the mixing or subversion of sexual identity cues, cross-gender and fetish dress and/or BDSM sex spaces and public performances. Moreover, it is through playing with, mixing and queering multiple conventions of music performance and sexual identity performances that the queer scene distinguishes itself from mainstream gay culture and wages its assault on both gay and straight cultural norms.

Highlighting the centrality of music to the queer scene, PJ comments that 'music has been a binder of the queer community ... because the queer scene has been ... a dance scene, a music scene ... burgeoning in the clubs where you could escape the rest of the world' (pers. comm.). Yet, unlike the gay scene, a uniformed musical taste culture is remarkably absent from the queer scene. Rather than exhibiting a strong appreciation for a single or closely associated collection of musical genres, the queer scene collectively expresses a dislike for one particular style of music which is handbag music. 'One of the main reasons we started Omo [says KD] was so you could go out and be with queer people and not have to listen to that top-40 remix bullshit' (pers. comm.). Similarly, on the official Cut and Taste website organizers claim that Cut and Taste is 'an alternative to handbag dance parties and camp vocal house for the Queer community of Brisbane'. 
The music that is deejayed at all three events is a variation of dance and rock styles including electro, tribal, dirty house, industrial, alternative and punk. Omo and Cut and Taste are particularly keen to encourage new and emerging deejays to the decks and make a conscious effort to accommodate as many tastes as possible, ensuring that the musical styles vary over the course of the evening. Referring again to Cut and Taste's website,

[Cut and Taste] is about sampling different flavours, and putting together something new each time for a really vibrant scene of creative people. We aim to please, and every event is different. You can never know what to expect. But one thing is for sure-the music is deep, phat, dirty, electronic and totally twisted. Handbag, this ain't!

Resident deejay of the Wickham and Fluffy, NC, further differentiates between the musical characteristics and/or expectations of the gay and queer scene participants. Talking about her own experiences as a deejay at the Wickham she comments:

On a Thursday night at the Wickham, there’s not that many people and they want to hear all the hits, some Abba, the Village People, Kylie and a bit of Pink. But I still always introduce new music but in such a way that it keeps the same groove and atmosphere going 'cause if you change it they're going to go 'what's this shit' and walk off regardless of whether it's a good song or not. ... In a queer space you've got the room to be a lot more creative, a lot more experimental where as in a gay space you're limited and it’s frustrating because sometimes I don't want to be asked to play Kylie, some nights I might feel like playing Kylie, but other nights you think to yourself 'can I have one night where I don't get asked to play Kylie’. (pers. comm.)

As I have demonstrated, drag queening is the staple form of live/lip-synced musical performance in Brisbane's mainstream gay venues. In contrast to this, queer spaces offer scene participants a variety of live musical performances that help to create a unique shifting musical dynamic at each scene event. 'If it's dance music all night then everyone just hides in their little corners. But live music and performance in the queer scene is almost like an injection of adrenaline into the night' says PJ (pers. comm.). Between 2004-2006 Omo regularly showcased performances by local queer punk band Anal Traffic. In the year that Cut and Taste has been running it has featured live performances by local darkwave ambient outfit Dizzygotheca and electro rock singer/songwriter and bassist Zia. As part of the three Taboo events to date, organizers have offered scene participants an alternative to low camp gay male drag by hosting fetish fashion parades and showcasing performances by local drag king and bio queer performance troupe The Gang Stars. The musical sketch comedy style of The Gang Stars is radically different to the mainstream drag in Brisbane. Featuring a female cast who perform a variety of fem, butch and drag king roles, the Gang Stars explore the multiple manifestations of queer lesbian sexual identity demonstrating that lesbian sexuality can be expressed through a fluid multiplicity of gender performances.

Table 1 succinctly displays the most prevalent styles of live musical performance as well as the most common styles of music deejayed at gay and queer club events in Brisbane over a period beginning February 2004, ending November 2007. The diversity of musical genres and performance styles outlined in this table emphasizes the musical eclecticism that is a feature of the queer scene. 
Table 1: Featured musical styles at Brisbane's gay and queer club events

\begin{tabular}{|c|c|c|c|c|c|c|}
\hline & \multicolumn{3}{|c|}{ Brisbane Gay Music Scene } & \multicolumn{3}{|c|}{ Brisbane Queer Music Scene } \\
\hline & $\begin{array}{c}\text { The } \\
\text { Wickham }\end{array}$ & The Beat & Fluffy & OMO & Cut and Taste & Taboo \\
\hline 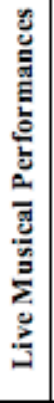 & $\begin{array}{l}\begin{array}{l}\text { Drag Queen } \\
\text { troupe }\end{array} \\
\text { Occasional live } \\
\text { female vocal } \\
\text { performances to } \\
\text { pre-recorded } \\
\text { backing by } \\
\text { commercially } \\
\text { successful guest } \\
\text { artist. }\end{array}$ & $\begin{array}{l}\text { Drag Queen } \\
\text { troupe }\end{array}$ & $\begin{array}{l}\text { Drag Queen } \\
\text { troupe } \\
\text { Occasional live } \\
\text { female vocal } \\
\text { performances to } \\
\text { pre-recorded } \\
\text { backing by } \\
\text { commercially } \\
\text { successful guest } \\
\text { artist. }\end{array}$ & $\begin{array}{l}\text { Anal Traffic } \\
\text { (Punk) }\end{array}$ & $\begin{array}{l}\text { Dizzygotheca } \\
\text { (Darkwave } \\
\text { Ambient) } \\
\text { Zia } \\
\text { (Electro rock) }\end{array}$ & $\begin{array}{l}\text { Drag king and bio } \\
\text { queen } \\
\text { performance } \\
\text { troupe }\end{array}$ \\
\hline 窇 & $\begin{array}{l}\text { Vocal House } \\
\text { Commercial } \\
\text { Dance } \\
\text { Uplifting Trance }\end{array}$ & $\begin{array}{l}\text { Vocal House } \\
\text { Commercial } \\
\text { Dance } \\
\text { Disco }\end{array}$ & $\begin{array}{l}\text { Vocal House } \\
\text { Commercial } \\
\text { Dance } \\
\text { Uplifting Trance }\end{array}$ & $\begin{array}{l}\text { Electro } \\
\text { Dirty House } \\
\text { Punk Rock } \\
\text { Alternative }\end{array}$ & $\begin{array}{l}\text { Electro } \\
\text { Dirty House } \\
\text { Tribal }\end{array}$ & $\begin{array}{l}\text { Electro } \\
\text { Dirty House } \\
\text { Industrial }\end{array}$ \\
\hline 丞 & \multicolumn{3}{|c|}{$\begin{array}{l}\text { Commercial dance music, vocal house and uplifting trance } \\
\text { are the dominant styles heard at all three gay clubs } \\
\text { surveyed. Similarly, lip synced drag queen performances } \\
\text { accompanied by a chorus of dancing boys accounts for the } \\
\text { dominant style of live musical performance. }\end{array}$} & \multicolumn{3}{|c|}{$\begin{array}{l}\text { While electro and dirty house are the most common genres } \\
\text { heard at all three queer events they are by no means } \\
\text { exclusive as a variety of alternative and rock genres are also } \\
\text { evident. Live performance is also considerably varied, with } \\
\text { each queer event offering a radically different form of live } \\
\text { musical entertainment. }\end{array}$} \\
\hline
\end{tabular}

The balance of power between queer scene organizers, deejays and musical performers is distributed equally amongst both women and men. Omo, which was established by men, has always featured an equal mix of both male and female deejays and showcased mixed sex bands and musical acts. Cut and Taste, which was started by a woman then promoted by a female and male duo has similarly featured both female and male deejays and live performers at its events. And finally, Taboo, which is run by women, has fostered a supportive female network that encourages female deejays and live performers while also welcoming men. Furthermore, the sex, gender and sexual identities of queer scene participants are also wide-ranging and non-discriminatory. While it is clear from observing and participating in this scene that same-sex sexual desire is the most prominent commonality amongst scene members, this is by no means an exclusive feature as polymorphous sexual expressions (including heterosexuality) are evident both in the partnering of scene participants and via the public sex play that occurs at queer events.

Unlike the aforementioned gay venues, Omo, Cut and Taste and Taboo all accommodate diverse expressions of gender and sexuality and facilitate cross-gender and mixed sex play. This is particularly significant as the gay scene rarely encourages sex play outside of designated sex clubs. In Brisbane, gay sex clubs are open to men only, further highlighting the gender segregation that is typical of the gay scene. The style of sex play varies across the events: Omo has hosted BDSM and sex on premises spaces in which both homosexual and heterosexual activity was evident. Cut and Taste and Taboo have provided play-rooms ${ }^{\mathrm{xi}}$ open to all scene participants who may choose to either participate or observe and have featured live sex play shows by experienced members of the BDSM and fetish communities. Among the queer scene, the general feeling towards BDSM sex play is that it is an empowering and confronting act that signifies a multiplicity of pleasures ${ }^{x i i}$. Theoretically, it offers its participants a form of momentary escape from sexual repression, specifically because it can be understood as a subversive way of creating new possibilities of pleasure that lie outside the naturalistic and medicalized notions of desire perpetuated by dominant culture (Foucault 1997). Furthermore, as Sullivan suggests, it is 'a strategic game, a political practice of queer pleasure that functions to denaturalise sexuality' $(2003,156)$, because it allows for a reconceptualization of pleasure that removes gender as the determining factor of one's sexual object choice. 


\section{Conclusion}

The emergence of a queer scene in Brisbane is not a distinct local phenomena, as Buckland (2002), Ciminelli and Knox (2005), du Plessia and Chapman (1997) ${ }^{\text {xiii }}$ and Halberstam (2005) have all written about queer scenes located across the globe that form on the basis of their marginal gender and sexual identities and their appreciation for particular styles of music. Like these scenes, the Brisbane queer scene is also an example of a scene formed by people with marginal gender and sexual identities (be they homosexual or heterosexual); people who felt a need to express themselves in a manner that no other local scene accommodated; people who craved an alternative to the music and the social conduct of the gay mainstream. Of course this research is not complete, as further work needs to be done in relation to other Australian queer scenes to determine whether this is in fact a localized occurrence or if it is a local manifestation of translocal queer scenes across Australia and possibly the world. And as Halberstam has suggested, when alliances exist between minority academic fields and minority cultural production as they do here, it is the responsibility of the queer academic to 'participate in the ongoing project of recording and interpreting queer culture and circulating a sense of its multiplicity and sophistication' $(2005,159)$.

We may ask then: What makes Brisbane’s queer scene worthy of such investigation? Musical play and live performance as well as sexual play and live performance are distinguishing features of the local queer scene, setting it apart from the gay mainstream, and as the relative theories on queer and musical identities suggest, important identity work takes place at both sites of play. The identity work in progress here is an interrogation of the preconditions of mainstream gay identity and its follow on effects such as emerging patterns of musical taste. The lack of genre specific or codified musical tastes and performances within the queer scene correlates with queer's disidentificatory position. By defying collective sexual and musical classifications, the queer scene activates its resistance towards commodified aestheticism that is determined on the grounds of sexual identification. In opposition to the social limitations imposed upon expression of sexuality by the gay mainstream as well as the gay scene's preoccupation with handbag music, Brisbane’s queer scene encourages eclectic expressions of sexual and musical play. It is through playing with multiple conventions and representations of gender and sexual norms, as well as musical norms, that queers activate a serious aesthetic challenge to gay cultural normativity. In doing so, they demonstrate the indeterminacy and elasticity that is characteristic of queer identity and queer cultural production in general.

\section{Notes}

\footnotetext{
${ }^{\mathrm{i}}$ Referring to the collective spending power of lesbians and gays, the pink dollar regulates lesbians and gays as a consumer group.

${ }^{\mathrm{i}}{ }_{\mathrm{ii}}$ Another example of this is the Bravo Company's production of the television series Queer Eye for the Straight Guy in which five gay men are employed to 'make-over' a straight man. This show perpetuates a very narrow stereotype of the gay male as effeminate, fashion-conscious and superficial, and turns sexual identity into a marketable commodity. This and other examples of the commodification of queer identity can be found in Whitney (2006).

${ }^{\text {iii }}$ My role as an overt participant observer of gay and queer musical cultures is directly related to my 'insider status' or complete membership in the Brisbane scene. Adler and Adler (1987) argue that deeper levels of understanding are available to the complete member because of their insider position and their closer and more regular contact with the field.

${ }^{\text {iv }}$ ACT UP (or the AIDS Coalition to Unleash Power) was formed in New York during 1987 and later spread to other American, European and Australian cities. ACT UP's aim is to raise awareness of the AIDS crisis and demand effective and affordable drug treatment. It does this through a variety of methods including political negotiation and non-violent dramatic acts of civil disobedience. Further information can be found at www.actup.org

${ }^{\mathrm{v}}$ Beginning in 1998, Queeruption is a global network of alternative, radical and disenfranchized queers. Queeruption stages a festival that takes place in different cities around the world every year. Further information can be found at www.queeruption.org
} 


\footnotetext{
${ }^{\mathrm{vi}}$ It should be noted that The Beat is called a megaclub because it actually hosts five distinctive nightclubs spaces, seven bars and three 'chill-out' areas in one building. However, when reference to the Beat is made in the context of this investigation I am specifically referring to what is known colloquially as 'up-stairs at the Beat' which is the club's 'gay' area.

vii This list of artists is provided merely as a reference and is by no means a complete guide to the music played at these venues. For a detailed account of the deejay sets and style of music played at these venues consult their websites: http://www.thewickham.com.au; http://www.thebeatmegaclub.com.au; http://www.fluffy.com.au

${ }_{\text {viii }}$ For example, Kylie Minogue has been invited to headline the $30^{\text {th }}$ annual Gay and Lesbian Mardi Gras in Sydney in 2008, while Madonna has in the past performed in London's infamous G.A.Y nightclub, and is a popular source of inspiration for various drag performers throughout Western gay culture.

${ }^{\text {ix }}$ Scene picture can be viewed online by visiting the websites of Queensland Pride (http://qlp.e-p.net.au/) and Qnews (http://www.qnews.com.au/) and clicking on the 'scene pics' link.

${ }^{x}$ While Omo ceased running throughout the course of this research, in 2007 the organizers of Omo teamed up with other members of the queer scene and launched a new event called Skank which has maintained Omo's original queer politic.

${ }^{x i}$ A play-room is a space in which a variety of sexual acts such as rope play or whipping may occur, however such spaces usually do not allow for intercourse due to legislation governing the venues in which these events take place.

xii Stoddart (2004) has conducted research in queer BDSM space and identity and has similarly found that participants identify BDSM spaces as a 'confronting', 'enjoyable' and 'playful'.

xiii Buckland (2002) has focused specifically on dance club culture in New York. Ciminelli and Knox (2005) and du Plessia and Chapman (2005) have focused the translocal queercore scenes of North America.
}

\section{Author's Biography}

Jodie Taylor is a PhD candidate at the Queensland Conservatorium, Griffith University, Brisbane, Australia. Currently she lectures at Griffith University in music technology; sound composition; aesthetics; music, gender and sexuality. Her research interests include futurism, industrial music, drag queercore and queer theory. She has previously published on issues relating to queer identities and popular music practices.

\section{References}

Adler, P.A. and Adler, P. 1987. Membership roles in field research. Newbury Park, CA: Sage.

Buckland, F. 2002. The impossible dance: Club culture and queer world-making. Middletown, CT: Wesleyan University Press.

Butler, J. 1990. Gender trouble: Feminism and the subversion of identity. London: Routledge.

Butler, J. 1993. Bodies that matter: On the discursive limits of sex. New York: Routledge.

Butler, J. 2001. The desire of philosophy. Lolapress 2. http://www.lolapress.org/elec2/artenglish/butl_e.htm

Ciminelli, D. and Knox, K. 2005. Homocore: The loud and raucous rise of queer rock. Los Angeles: Alyson books.

Connell, J. and Gibson, C. 2003. Sound tracks: Popular music, identity and place. London: Routledge.

Corber, R. and Valocchi, S. 2003. [Introduction]. In Queer studies: An interdisciplinary reader, ed. R. Corber and S. Valocchi, 1-17. Oxford, England: Blackwell. 
Currid, B. 1995. "We are family” House music and queer performativity. In Cruising the Performative: Interventions into the repression of ethnicity, nationality and sexuality, ed. S.E. Case, P. Brett and S. Foster, 165-196. Bloomington, IN: Indiana University Press.

DeChaine, R. 1997. Mapping subversion: Queercore music’s playful discourse of resistance. Popular music and society 21(4): 7-37.

DeNora, T. 2000. Music in everyday life. Cambridge, England: Cambridge University Press.

du Plessia, M. and Chapman, K. 1997. Queercore: The distinct identities of subculture. College Literature 24(1): 45-58.

Dyer, R. 1995. In defence of disco. In Out in culture: Gay, lesbian, and queer essays on popular culture, ed. C. K. Creekmur and A. Doty, 407-415. Durham, NC: Duke University Press.

Edwards. T. 1998. Queer fears: Against the cultural turn. Sexualities 1(4): 471-484.

Feigen, B. 2000. Not one of the boys: Living life as a feminist. New York: Alfred A. Knopf.

Foucault, M. 1997. Sex, power and the politics of identity. In Michel Foucault: Ethics, subjectivity and truth, ed. P. Rainbow, 163-173. New York: The New Press.

Frith, S. 1987. Towards an aesthetic of popular music. In Music and society: The politics of composition, performance and reception, ed. R. Leppert and S. McClary, 133-150. Cambridge, England: Cambridge University Press.

Fritz, J. 1999. Rave culture: An insider's overview. Victoria, BC: Small Fry Publications.

Gelder, K. and Thornton, S. ed. 1997. The subcultures reader. London: Routledge.

Gill, J. 1995. Queer noises. London: Cassell.

Halberstam, J. 1998. Female masculinity. Durham, NC: Duke University Press.

Halberstam, J. 2005. In a queer time and place: Transgender bodies, subcultural lives. New York: New York University Press.

Hargreaves, D.J., Miell, D. and MacDonald, R.A.R. 2002. What are musical identities, and why are they important? In Musical identities, ed. R.A.R. MacDonald, D.J. Hargreaves and D. Miell, 1-20. Oxford, England: Oxford University Press.

hooks, b. 1992. Black looks: Race and representation. Boston, MA: South End Press.

Jagose, A. 1996. Queer theory. Melbourne, Vic: Melbourne University Press.

McClary, S. 1991. Feminine endings: Music, gender and sexuality. Minneapolis, MN: University of Minnesota Press.

Meyer, M. (1994). [Introduction]. In The politics and poetics of camp, ed. M. Meyer, 1-22. London: Routledge. 
Moore, C. 2001. Sunshine and rainbows: The development of gay and lesbian culture in Queensland. St. Lucia, Qld: University of Queensland Press.

Morris, M. 2006. Stories coming out. Review of Love saves the day: A history of American dance music culture, 1970-1979 by T. Lawrence; The fabulous Sylvester: The legend, the music, the seventies in San Francisco by J. Gamson; Listening to the sirens: Musical technologies of queer identity from Homer to Hedwig by J. Peraino. Journal of Popular Music Studies 18(2): 220-240.

Peterson, R. A. and Bennett, A. 2004. Introducing music scenes. In Music scenes: Local, translocal, and virtual, ed. A. Bennett and R. A. Peterson, 1-16. Nashville, TN: Vanderbilt University Press.

Phelan, P. 1993. Crisscrossing cultures. In Crossing the stage: Controversies on cross-dressing, ed. L. Ferris, 155-170. London: Routledge.

Phelan, S. 1997. [Introduction]. In Playing with fire, queer politics queer theories, ed. S. Phelan, 1-8. New York: Routledge.

Plummer, K. 1998. Afterward: The past, present and futures of the sociology of same-sex relations. In Social perspectives in lesbian and gay studies, ed. P.M. Nardi and B.E. Schneider, 605-614. London: Routledge.

Reynolds, R. 2002. From camp to queer: Remaking the Australian homosexual. Melbourne, Vic: Melbourne University Press.

Rietveld, H.C. 2004. Ephemeral spirit: Sacrificial cyborg and communal soul. In Rave culture and religion, ed. G. St. John, 46-61. London: Routledge.

Sedgwick, E.K. 1993. Tendencies. Durham, N.C: Duke University Press.

Stoddart, J. 2007. Queer workshopping: Constructions of self, space and perverse toys. In Proceedings from the Queer Space: Centres and Peripheries Conference. Conference held in Sydney, NSW. Presented by the Sydney University of Technology. http://www.dab.uts.edu.au/conferences/queer_space/proceedings/

Sullivan, N. 2003. A critical introduction to queer theory. Armidale, Vic: Circa Books.

Sycamore, M.B. 2004. [Introduction]. In That's revolting! Queer strategies for resisting assimilation, ed. M.B. Sycamore, 1-6. Brooklyn, NY: Soft Skull Press.

Thornton, S. 1997. The social logic of subcultural capital. In The subcultures reader, ed. K. Gelder and S. Thornton, 200-212. London: Routledge.

Whitney, E. 2006. Capitalizing on camp: Greed and the queer marketplace. Text and Performance Quarterly 26(1): 36-46.

Wotherspoon, G. 2001. From sub-culture to mainstream culture: Some impacts of homosexual and gay sub-cultures in Australia. Journal of Australian Studies 28: 56-62. 